\title{
Intraluteal regulation of prostaglandin F2 $\alpha$-induced prostaglandin biosynthesis in pseudopregnant rabbits
}

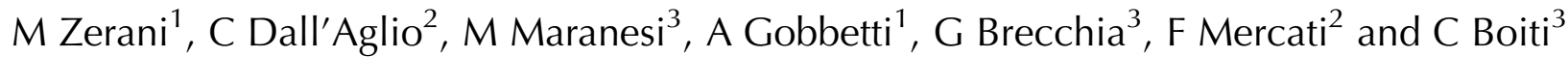 \\ ${ }^{1}$ Dipartimento di Biologia Molecolare, Cellulare e Animale, Università di Camerino, via F. Camerini 1, I-62032 \\ Camerino, Italy, Dipartimento di Scienze biopatologiche ed Igiene delle produzioni animali e alimentari, ${ }^{2}$ Sezione di \\ Anatomia veterinaria and ${ }^{3}$ Laboratorio di Biotecnologie fisiologiche, Sezione di Fisiologia veterinaria, Università degli \\ Studi di Perugia, via S. Costanzo 4, I-06100 Perugia, Italy
}

Correspondence should be addressed to C Boiti; Email: cristiano.boiti@unipg.it

\begin{abstract}
The objective of the present study was to investigate in rabbit corpora lutea $(\mathrm{CL})$, at both the cellular and molecular level, intraluteal cyclooxygenase (COX)-1, COX-2 and prostaglandin (PG) E2-9-ketoreductase (PGE2-9-K) enzymatic activities as well as in vitro PGE2 and PGF2 $\alpha$ synthesis following PGF2 $\alpha$ treatment at either early- (day-4) or mid-luteal (day-9) stage of pseudopregnancy. By immunohistochemistry, positive staining for COX-2 was localized in luteal and endothelial cells of stromal arteries at both the stages. In CL of both stages, basal COX-2 mRNA levels were poorly expressed, but rose $(P<0.01) 4$ - to 10-fold 1.5-6 $\mathrm{h}$ after treatment and then gradually decreased within $24 \mathrm{~h}$. Compared to mid-stage, day-4 CL had lower $(P<0.01) \mathrm{COX}-2$ and PGE2-9-K basal activities, and PGF2 $\alpha$ synthesis rate, but higher $(P<0.01)$ PGE2 production. Independent of luteal stage, PGF2 $\alpha$ treatment did not affect COX-1 activity. In day-4 CL, PGF2 $\alpha$ induced an increase $(P<0.01)$ in both COX-2 activity and PGF2 $\alpha$ synthesis, whereas that of PGE2 remained unchanged. In day-9 CL, PGF2 $\alpha$ up-regulated $(P<0.01)$ both COX-2 and PGE-9$K$ activities, and PGF2 $\alpha$ production, but decreased $(P<0.01)$ PGE2 synthesis. All changes in gene expression and enzymatic activities occurred within $1.5 \mathrm{~h}$ after PGF2 $\alpha$ challenge and were more marked in day-9 CL. Our data suggest that PGF2 $\alpha$ directs intraluteal PG biosynthesis in mature CL, by affecting the CL biosynthetic machinery to increase the PGF2 $\alpha$ synthesis in an autoamplifying manner, with the activation of COX-2 and PGE-9-K; this may partly explain their differentially, age-dependent, luteolytic capacity to exogenous PGF2 $\alpha$ in rabbits.

Reproduction (2007) 133 1005-1016
\end{abstract}

\section{Introduction}

The corpora lutea $(\mathrm{CL})$ are transient ovarian organs that play a critical role for the establishment and maintenance of pregnancy by secreting progesterone (Niswender et al. 2000). However, if pregnancy fails to occur, the $\mathrm{CL}$ undergo luteolysis, a dynamic regression process that ends with their complete functional and structural demise (McCracken et al. 1999).

It is now widely accepted that prostaglandins (PGs) play a key role in regulating the function and life span of CL. In fact, PGF2 $\alpha$ has been identified as the main luteolysing factor of uterine origin in several non-primate mammals including the rabbit (O'Grady et al. 1972, Keyes \& Bullock 1974, Lytton \& Poyser 1982), and PGE2 as an important luteoprotective factor with luteotrophic or antiluteolytic actions (Niswender et al. 2000). In many species, the CL themselves synthesize PGF2 $\alpha$ and PGE2 (Gobbetti et al. 1999, Boiti et al. 2000, Diaz et al. 2002, Zerani et al. 2005), whose production is regulated by a large array of local and systemic factors, suggesting a paracrine and autocrine role for these two PGs (Olofsson \& Leung 1996, Davis \& Rueda 2002, Diaz et al. 2002, Wiltbank \& Ottobre 2003, Arosh et al. 2004, Boiti et al. 2005).

The critical step in PG biosynthesis is the enzymatic conversion of phospholipase A2-derived arachidonic acid into PGH2 by cyclooxygenase- 1 (COX-1) or COX-2 (Smith et al. 1996, Sakurai et al. 2003, 2005, Simmons et al. 2004). PGH2, in turn, is converted into four structurally active PGs (PGE2, PGF2 $\alpha$, PGD2 and PGI2) via specific PG synthases (Helliwell et al. 2004). However, the biosynthesis of PGF2 $\alpha$ is peculiar because it derives from three different pathways catalysed by corresponding ketoreductases using PGH2, PGD2 or PGE2 as substrates (Watanabe 2002). In rabbits, the PGE2-9-ketoreductase (PGE2-9-K) was found in the ovary (Schlegel et al. 1987) and more recently also in CL (Wintergalen et al. 1995). 
Although in the past few years the down-stream mechanisms activated by exogenous PGF $2 \alpha$ received much attention in rabbits (Boiti et al. 1998, 2000, 2003, Gobbetti et al. 1999), the possible autocrine and/or paracrine roles of PGF2 $\alpha$ in this species are still poorly understood. Similarly, little is known about what mechanisms do protect the growing $\mathrm{CL}$ from functional luteolysis, which occurs in the early luteal stage until day 6 of pseudopregnancy, when CL shift from refractoriness to partial responsiveness to exogenous PGF2 $\alpha$ (Boiti et al. 1998).

Therefore, the main objective of this study was to compare, in the rabbit model, the key enzymes involved in the PGs biosynthesis, and their intraluteal modulation after induction of $\mathrm{CL}$ regression by means of PGF2 $\alpha$ administered at either early- or mid-luteal stage of pseudopregnancy, at days 4 and 9 respectively. With this end in view, experiments were devised to characterize the dynamic of gene expression patterns for luteal COX-2, its precise cell type localization within the ovary, as well as the in vitro rates of enzymatic activity for COX1, COX-2 and PGE2-9-K and for the synthesis of PGE2 and PGF $2 \alpha$ on CL explanted at different time points up to $24 \mathrm{~h}$ after PGF2 $\alpha$ treatment.

\section{Materials and Methods}

\section{Reagents}

Random hexamer primers, DNase I (DNAase I Amp. Grade), RNAse H- reverse transcriptase (Superscript II), Escherichia coli RNase $\mathrm{H}$ and DNA ladders were obtained from Invitrogen as well as reagent for isolation and purification of total RNA (TRIzol), Taq DNA polymerase (Platinum), RNAse-free tubes and RNAsefree water and deoxy-NTPs. Primers for $18 \mathrm{~S}$ rRNA and corresponding competimers (QuantumRNA 18S Internal Standards) were acquired from Ambion (Austin, TX, USA), whereas primers for mRNAs of COX-2 were obtained from Invitrogen. Nucleospin Extract II kit for DNA extraction from agarose gels was from MachereyNagel (Düren, Germany). Tritiated hormones and arachidonic acid were purchased from Amersham Biosciences, while progesterone, PGF2 $\alpha$ and PGE2 antisera, and non-radioactive hormones came from Sigma. The kit for the protein assay was purchased from Bio-Rad Laboratories. The primary polyclonal antibody goat anti-COX-2, used for immunohistochemistry was supplied by Santa Cruz Biotechnology (Santa Cruz, CA, USA), whereas the biotinylated secondary antibody, chicken anti-goat IgG and normal chicken serum were purchased from Santa Cruz Biotechnology. The avidin-biotin complex (ABC; Vector Elite Kit) and the chromogen 3,3'-diaminobenzidine tetrachloride (DAB) were from Vector Laboratories. Silica gel 60 were purchased from Baxter (Baxter Scientific Products,
McGaw Park, IL, USA), whereas all the other pure grade chemicals and reagents were obtained locally.

The following hormonal preparations were administered via i.m. injection: gonadotrophin-releasing hormone $(\mathrm{GnRH})$ analogue (Receptal, Hoechst-Roussel Vet, Milan, Italy), Pregnant mares serum gonadotrophin (PMSG; Folligon, Intervet, Milan, Italy) and alfaprostol (Gabbrostim, Centralvet, Milan, Italy) a PGF $_{2 \alpha}$ analogue.

\section{Animals, hormonal regimen and luteal tissue collection}

The protocols involving the care and use of the animals for these experiments were approved by the Bioethic Committee of the University of Perugia.

Unmated New Zealand White rabbits of 5-months age, weighing $3.5-3.8 \mathrm{~kg}$, were caged individually in quarters of the University of Perugia Central Animal Facility and maintained under controlled conditions of light (14 h light: $10 \mathrm{~h}$ darkness) and temperature $\left(18^{\circ} \mathrm{C}\right)$. The animals were provided commercial rabbit chow and drinking tap water ad libitum. All rabbits were treated with $20 \mathrm{IU}$ of PMSG followed 3 days later by an i.m. injection of $0.8 \mu \mathrm{g}$ of $\mathrm{GnRH}$ to induce pseudopregnancy (Stradaioli et al. 1997). The day of $\mathrm{GnRH}$ injection is designated day 0 . This hormonal protocol was effective in inducing pseudopregnancy.

On day 4 or 9 of pseudopregnancy, the rabbits $(n=$ 18/group) were administered i.m. $200 \mu \mathrm{g}$ alfaprostol. At each luteal stage, three rabbits were killed by cervical dislocation just before (time 0 ) and then 1.5, 3, 6, 12 and $24 \mathrm{~h}$ after PGF2 $\alpha$ administration. Reproductive tracts, promptly removed from each animal, were thoroughly washed with saline. Within a few minutes, the CL were excised from ovaries and, after careful dissection of nonluteal tissue by fine forceps under stereoscopic magnification, immediately frozen at $-80{ }^{\circ} \mathrm{C}$, after rinsing with RNAse-free PBS, for later evaluation of gene expression, or processed for in vitro determination of enzymatic activities and PG synthesis. For the immunohistochemical detection of COX-2, two additional animals for each time point were killed just prior (time $0), 1.5$ and $3 \mathrm{~h}$ after PGF2 $\alpha$ injection administered at either day 4 or 9 of pseudopregnancy. The ovaries, immediately excised after killing, were fixed by immersion in $4 \%(\mathrm{w} / \mathrm{v})$ formaldehyde in PBS $(\mathrm{pH} 7.4)$ for $24 \mathrm{~h}$ at room temperature, and subsequently processed for embedding in paraffin following routine tissue preparation procedures

Progesterone plasma levels were used as a marker of luteal functional activity. From each rabbit, two blood samples were collected by venous puncture of the marginal ear vein, one just before PGF $2 \alpha$ treatment and the other immediately prior to killing. The samples, collected in EDTA vacutainers, were centrifuged at $3000 \mathrm{~g}$ for $15 \mathrm{~min}$ and plasma was stored frozen until assayed for progesterone concentrations to assess the functional status of the ovarian CL. For the purpose of this 
work, functional luteolysis was defined as a 50\% decrease in plasma progesterone from pre-treatment values, while complete luteolysis as the failure of $\mathrm{CL}$ to secrete progesterone so that blood levels fall below $1.0 \mathrm{ng} / \mathrm{ml}$, which are found in oestrous rabbits (Browning et al. 1980).

\section{Progesterone assay}

Progesterone concentrations were determined by RIA, using specific antibody according to the procedure reported elsewhere (Boiti et al. 2000). Progesterone was extracted from corresponding $0.1 \mathrm{ml}$ plasma samples with ethyl ether and each sample was assayed in duplicate. The assay sensitivity was $0.08 \mathrm{ng} / \mathrm{ml}$ for progesterone, whereas intra- and interassay coefficients of variations were 5.3 and $10.2 \%$ respectively.

\section{Immunohistochemistry of COX-2}

The immunohistochemical detection of COX-2 was performed using a modification of a previously reported procedure (Boiti et al. 2005). Briefly, serial $7 \mu \mathrm{m}$-thick sections, mounted on poly-L-lysine coated glass slides, were dewaxed in xylene and hydrated through graded ethanol; then they were microwaved for $5 \mathrm{~min}$ at $750 \mathrm{~W}$ in $10 \mathrm{mM}$ citric acid ( $\mathrm{pH} \mathrm{6.0)}$ for antigen retrieval. All subsequent steps were carried out in a moist chamber at room temperature. The sections were first treated with a $0.5 \%$ solution of hydrogen peroxide in methanol for $10 \mathrm{~min}$, in order to inactivate the endogenous pseudoperoxidase activity, then rinsed with PBS solution and incubated for 30 min with normal chicken serum to minimize the non-specific binding of reagent in subsequent steps. To reduce the variation in staining, within each luteal stage, all tissue sections were incubated together. The primary antiserum, goat antiCOX-2 antibody (sc-1747) was diluted 1:50 in PBS and left on sections overnight. The next day, the sections were washed in PBS and incubated with a biotinylated secondary antibody (1:200 in PBS) for $30 \mathrm{~min}$. After PBS washes, sections were exposed to avidin-biotin-peroxidase complex (1:2500 in PBS) for $30 \mathrm{~min}$, followed by the chromogen $\mathrm{DAB}$ for $5 \mathrm{~min}$, to visualize the site of reaction. After washing in tap water, the ovary sections were dehydrated and mounted in Canada balsam natural. Positive reactions were recognized as reddish brown precipitates. Sections, in which the primary antibody was omitted or substituted by pre-immune goat gamma globulin, were used for the negative control of non-specific staining.

\section{$R N A$ extraction and $R T$}

For each rabbit, the total RNA was extracted from a pool of eight $\mathrm{CL}$, which was homogenized by Omni- $\mu \mathrm{H}$ mixer (Analytical Control, Dasit, Cinisello Balsamo, Milan,
Italy) in $1 \mathrm{ml}$ solution provided with Trizol as previously described (Boiti et al. 2003). Concentration of total RNA $\left(\mathrm{OD}_{260}\right)$ and purity $\left(\mathrm{OD}_{260 / 280}, \mathrm{OD}_{260 / 230}\right)$ were determined spectrophotometrically (BioPhotometer, Eppendorf srl, Milan, Italy). The integrity of each sample was assessed by electrophoresis of an aliquot of $3 \mu \mathrm{g}$ RNA in agarose formaldehyde gel using ethidium bromide staining. Genomic DNA contamination was prevented by treatment with deoxyribunoclease I according to instructions. Five microgram of total RNA $(1 \mu \mathrm{g} / \mu \mathrm{L})$ was reverse transcribed into cDNA in a $20 \mu \mathrm{l}$ final reaction mixture of iSCRIPT cDNA Synthesis Kit (Bio-Rad). Genomic DNA contamination was checked by carrying samples through PCR procedure without reverse transcriptase. The RT products were stored at $-20^{\circ} \mathrm{C}$.

\section{Muliplex RT-PCR amplification}

An aliquot (1.0 $\mu \mathrm{l}$ ) of cDNA was used as a template for the subsequent semi-quantitative PCR amplification reaction. This $(25.0 \mu \mathrm{l})$ was performed with $0.2 \mu \mathrm{l}$ Taq DNA Polymerase $(5 \mathrm{U} / \mu \mathrm{l}), 1.0 \mu \mathrm{l}$ dNTPs $(10 \mathrm{mM}), 5.0 \mu \mathrm{l} \mathrm{Taq}$ buffer $10 \times, 1.0 \mu \mathrm{l}(10 \mu \mathrm{M})$ of both forward and reverse primers. The primer sequences were: $\mathrm{COX}-2$, product size $121 \mathrm{bp}$, forward 5'-CCTCACTGATGGGCTGTTTT-3', reverse 5'-GGTGAAAGCAATGCCTGAAT-3'; 18S (accession n. 10098): product size bp: 489, forward 5'TCAAGAACGAAAGTCGGAGGTT-3', reverse 5'-GGACATCTAAGGGCATCA-3'. The semi-quantitative PCRs were carried out as reported previously (Boiti et al. 2005). Preliminary experiments were carried out to establish the optimal ratio between $18 \mathrm{~S}$ primers and their competimers. Between 30 and 40 cycles, both target and 185 products were in a linear exponential phase of amplification (data not shown). To minimize errors within each experiment, the target gene was co-amplified with housekeeping $18 \mathrm{~S}$ primers at the same PCR cycle. The amplification was performed on a thermal cycler (GeneAmp, PCR System, Perkin-Elmer Biosystem, Foster City, CA, USA). All PCR consisted of a first denaturing cycle at $94{ }^{\circ} \mathrm{C}$ for $75 \mathrm{~s}$, followed by an amplification profile of 35 reaction cycles with a first denaturing cycle at $94{ }^{\circ} \mathrm{C}$ for $15 \mathrm{~s}$, followed by annealing at $60{ }^{\circ} \mathrm{C}$ for $30 \mathrm{~s}$ and extension at $72{ }^{\circ} \mathrm{C}$ for $45 \mathrm{~s}$ and a final extension step at $72{ }^{\circ} \mathrm{C}$ for $10 \mathrm{~min}$. Within each experiment, the complete set of samples was processed in parallel in a single PCR, using aliquots of the same PCR master mix. Each set of determinations was performed in triplicate.

\section{Analysis of amplification products}

The amplified PCR-generated products $(20 \mu \mathrm{l}$ of $25 \mu \mathrm{l}$ total reaction volume) were analysed by electrophoresis on $2 \%$ agarose gel using ethidium bromide staining. One product for each time point was electrophoresed on a 
single gel together with a negative control that contained no RNA and standard DNA ladder. The images of gels were acquired using a Kodak DC290 digital camera. The background-corrected band intensities (absolute optical densities with the background levels from corresponding lanes subtracted for each PCR product) were quantified using Quantity One software (Bio-Rad Laboratories). To evaluate the temporal changes in relative levels of mRNAs, the band intensities for the target genes of interest obtained from each aliquot of PCR products were normalized against those of the housekeeping $18 \mathrm{~S}$ mRNA co-amplified product in the same aliquot. Values were expressed as arbitrary units of relative abundance of the specific target genes.

The amplified products, collected from agarose gel after electrophoresis, were purified with Nucleospin Extract II kit and their identity confirmed by DNA sequencing with Sanger's method.

\section{COX-1 and COX-2 enzyme activity determination}

Luteal COX-1 and -2 activities were determined by measuring the disappearance of the radiolabelled substrate $\left[{ }^{3} \mathrm{H}\right]$ arachidonic acid using a modified method previously reported (Xu et al. 1997). Three to four CL of each rabbit were pooled and homogenized in $1 \mathrm{ml}$ cold fresh buffer (50 mM Tris- $\mathrm{HCl}$ and $1 \mathrm{mM}$ EDTA, $\mathrm{pH}$ 8.0), centrifuged at $20000 \mathrm{~g}$ for $60 \mathrm{~min}$ at $4{ }^{\circ} \mathrm{C}$, and the supernatant was used for subsequent determination of enzyme activity in duplicate. To each incubation tube $50 \mu \mathrm{l}$ supernatant and $50 \mu \mathrm{l}$ buffer were added, containing 150000 d.p.m. $\left[{ }^{3} \mathrm{H}\right]$ arachidonic acid (specific activity $150-230 \mathrm{Ci} / \mathrm{mmol}$ ), either alone or with a selective COX-2 inhibitor (NS-398 $1 \mu \mathrm{M}$ ). The sample and substrate mixture with a non-selective COX inhibitor (acetylsalicylic acid, $1 \mathrm{mM}$ ) was used to determine the $\left[{ }^{3} \mathrm{H}\right]$ arachidonic acid disappearance values due to other enzymatic activities (lipoxygenase and/or epoxygenase) and non-enzymatic reactions (Parthasarathy et al. 1989). The mixture was then incubated at $37{ }^{\circ} \mathrm{C}$ for $30 \mathrm{~min}$. Termination was achieved by addition of isopropanol $/ n$-heptane $/ 1 \mathrm{~N}$ sulphuric acid $(1: 4: 0.1, v / v / v)$. The phases were separated by the addition of $400 \mu \mathrm{l} \mathrm{H}_{2} \mathrm{O}$ and $1 \mathrm{ml} n$-heptane. The upper organic layer, containing the unreacted $\left[{ }^{3} \mathrm{H}\right]$ arachidonic acid was transferred to a second tube and the aqueous layer was extracted again with $1 \mathrm{ml} n$-heptane. The organic layers were combined with an additional $1 \mathrm{ml}$ $n$-heptane and approximately $150 \mathrm{mg}$ silica gel 60 . The mixture was thoroughly mixed and centrifuged. The clear supernatant was transferred to a scintillation vial and the amount of $\left[{ }^{3} \mathrm{H}\right]$ arachidonic acid quantified by liquid scintillation counting. For each sample, COX-1 activity was determined by calculating the rate of loss of $\left[{ }^{3} \mathrm{H}\right]$ arachidonic acid incubated with selective COX-2 inhibitor. Conversely, the COX-2 activity of each corresponding sample was determined by calculating the rate of loss of $\left[{ }^{3} \mathrm{H}\right]$ arachidonic acid incubated without selective COX-2 inhibitor, and subtracting from this value that of COX-1. The values for COX-1 and COX2 were corrected by subtracting the $\left[{ }^{3} \mathrm{H}\right]$ arachidonic acid disappearance values due to other enzymatic activities and non-enzymatic reactions. Preliminary evidence led to our choosing the incubation conditions and the minimum effective dose of COX-2 inhibitor used in the present in vitro study (Fig. 1).

\section{PGE2-9-K enzyme activity determination}

Luteal PGE2-9-K activity was determined by measuring the conversion of $\left[{ }^{3} \mathrm{H}\right] \mathrm{PGE} 2$ into $\left[{ }^{3} \mathrm{H}\right] \mathrm{PGF} 2 \alpha$ using a previously reported modified method (Gobbetti \& Zerani 1995a). Briefly, each pool of CL was homogenized in $1 \mathrm{ml}$ cold fresh homogenating buffer $\left(20 \mathrm{mM} \mathrm{K}_{2} \mathrm{HPO}_{4}\right.$, $1 \mathrm{mM}$ EDTA and $10 \mathrm{mM} \beta$-mercaptoethanol, $\mathrm{pH}$ 7.4). Total homogenate was filtered and immediately used for the assay of enzymatic activity. One hundred microlitres of homogenate and $50 \mu \mathrm{l}$ of homogenating buffer containing 150000 d.p.m. $\left.{ }^{3} \mathrm{H}\right] \mathrm{PGE} 2$ (specific activity 140-170 Ci/mmol) and NADPH $(3 \mathrm{mg} / \mathrm{ml})$ were added to the incubation tube. The mixture was incubated at $37^{\circ} \mathrm{C}$ for $10 \mathrm{~min}$. Termination was achieved by addition of $100 \mu \mathrm{l} 0.1 \mathrm{M} \mathrm{HCl}$. PGs were extracted with diethyl ether and resuspended with $500 \mu \mathrm{l}$ RIA buffer $(74.5 \mathrm{mM}$ $\mathrm{Na}_{2} \mathrm{HPO}_{4}, 12.5 \mathrm{mM}$ EDTA-Na, $0.1 \%$ gelatine, $\mathrm{pH}$ 7.5). Two hundred microlitres RIA buffer containing PGF2 $\alpha-$ specific antiserum were added to duplicated samples and the mixture was incubated at $4{ }^{\circ} \mathrm{C}$ for $16 \mathrm{~h}$.

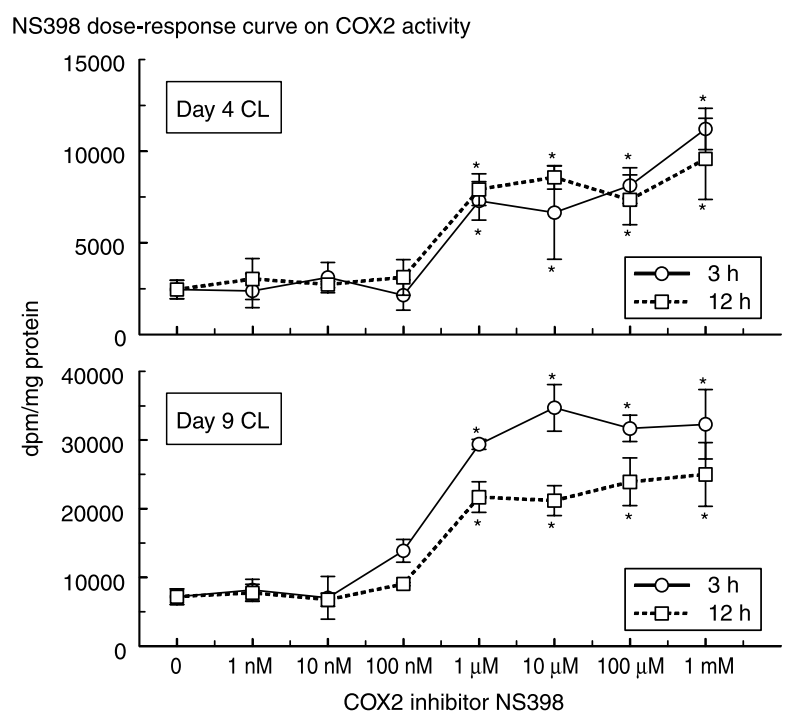

Figure 1 In vitro effects of increasing concentrations of COX-2 inhibitor (NS-398) on COX-2 activity by rabbit CL collected during early- and mid-luteal phases, at days 4 (upper panel) and 9 (lower panel) respectively, and incubated for 3 (circles) and 12 (squares) h. Each point represents mean \pm s.D. of three combined values. Asterisks indicate a significantly different value $(P<0.01)$. 
The $\left[{ }^{3} \mathrm{H}\right]$ PGF2 $\alpha$-antiserum bound fraction was determined as previously indicated.

\section{PGE2 and PGF2 $\alpha$ in vitro synthesis}

Luteal PGE2 and PGF2 $\alpha$ in vitro synthesis were determined by measuring the conversion of the $\left[{ }^{3} \mathrm{H}\right]$ arachidonic acid into $\left[{ }^{3} \mathrm{H}\right] \mathrm{PGE} 2$ and $\left[{ }^{3} \mathrm{H}\right] \mathrm{PGF} 2 \alpha$, using a previously reported modified method (Gobbetti \& Zerani 1995b). Fifty microlitres of supernatant, obtained by homogenizing each pool of $C L$ as previously described, and $50 \mu \mathrm{l}$ of incubation buffer (50 mM Tris, $1 \mathrm{mM}$ EDTA and 1 mM EGTA, pH 7.4) containing 150000 d.p.m. $\left[{ }^{3} \mathrm{H}\right]$ arachidonic acid were added to the incubation tube. The sample and substrate mixture with a non-selective COX inhibitor (indomethacin $1 \mathrm{mM}$ ) was used as a blank. The mixture was incubated at $37^{\circ} \mathrm{C}$ for 30 min and then stopped by addition of $100 \mu \mathrm{l} 0.1 \mathrm{M} \mathrm{HCl}$. PGs were extracted with diethyl ether and resuspended in $500 \mathrm{ml}$ RIA buffer. Two hundred microlitres RIA buffer containing PGE2- or PGF2 $\alpha$-specific antiserum were added to duplicated samples and the mixture was incubated at $4{ }^{\circ} \mathrm{C}$ for $16 \mathrm{~h}$. The $\left[{ }^{3} \mathrm{H}\right]$ PGE2- or $\left[{ }^{3} \mathrm{H}\right] \mathrm{PGF} 2 \alpha$-antiserumbound fractions were separated with charcoal-dextran suspension and the radioactivity was quantified by liquid scintillation counting.

\section{Statistical analysis}

At each stage of pseudopregnancy, the ratios of each PCR product for target COX-2 gene normalized against $18 \mathrm{~S}$ co-amplified product were analysed by two way ANOVA, time after PGF2 $\alpha$ treatment and gel being the two sources of variability (Sokal \& Rohlf 1981). Plasma progesterone levels, COX-1, COX-2 and PGE2-9-K enzyme activities as well as PGE2 and PGF2 $\alpha$ in vitro synthesis data were evaluated by ANOVA followed by Duncan's multiple range test (Duncan 1955). Correlation coefficients followed Sokal \& Rohlf (1981).

\section{Results}

\section{In vivo induction of luteolysis}

Progesterone plasma concentration, used as a marker of luteal functional activity, decreased in rabbits $8 \mathrm{~h}$ after PGF2 $\alpha$ injection at day 9 of pseudopregnancy, and complete functional regression was achieved $24 \mathrm{~h}$ later when it declined to $0.3 \mathrm{ng} / \mathrm{ml}$. As expected, PGF2 $\alpha$ was ineffective in inducing a functional regression when administered at day 4 of pseudopregnancy (Fig. 2).

\section{COX-2 immunolocalization in rabbit ovary}

Using a polyclonal antibody, immunostaining reaction for COX-2 was localized in different portions of un-treated (time 0 ) rabbit ovaries collected at days 4 (Fig. 3a-c) and 9

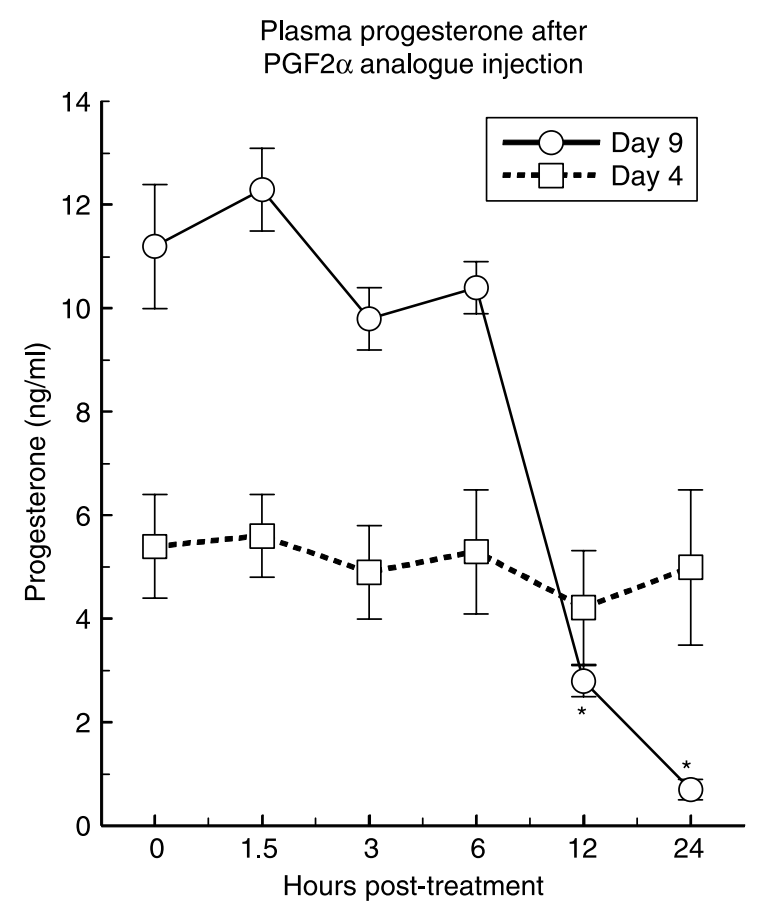

Figure 2 Plasma progesterone concentrations in blood samples collected at $0,1.5,3,6,12$ and $24 \mathrm{~h}$ after PGF $2 \alpha$ analogue injection at days 4 or 9 of pseudopregnancy. Apart from time 0 , each data point represents mean \pm S.E.M. of values derived from three different rabbits. Asterisks indicate a significantly different value $(P<0.01)$.

(Fig. 4a-c) of pseudopregnancy, including CL parenchyma (a, Figs 3 and 4), vascular components (b, Figs 3-5) and ovarian epithelium (c, Figs 3 and 4). In each positive cell type, staining was also evident 1.5 and $3 \mathrm{~h}$ after PGF2 $\alpha$ injection, independently of luteal stage at days 4 and 9 (data not shown). Staining was completely abolished when the primary antibody was substituted with non-immune serum ( $d-f$, Figs 3 and 4$)$.

\section{Gene expression of mRNA for luteal COX-2}

The corresponding base pair amplification products obtained using primer designed for the COX-2 gene matched the expected sizes (Fig. 6, panels, B and C). Sequence analysis showed that the $121 \mathrm{bp}$ PCR products were homologue to the published sequence of COX-2 cDNA for rabbits.

In un-stimulated rabbits, the relative COX-2 mRNA level was higher $(P<0.01)$ in mid- than in early phase $\mathrm{CL}$ (Fig. 6, panel A). At day 4 of pseudopregnancy, COX-2 mRNA transcript sharply increased tenfold $(P<0.01)$ already $1.5 \mathrm{~h}$ following PGF2 $\alpha$ treatment and remained at approximately this level for the next $24 \mathrm{~h}$ (Fig. 6, panel A). At day 9 of pseudopregnancy, the relative abundance of COX-2 mRNA rose threefold $1.5 \mathrm{~h}$ after PGF $2 \alpha$ administration and was fourfold $(P<0.01)$ more expressed 3 and $6 \mathrm{~h}$ later; thereafter, COX-2 mRNA levels gradually decreased within the following $24 \mathrm{~h}$, remained higher $(P<0.01)$ than pre-treatment basal 

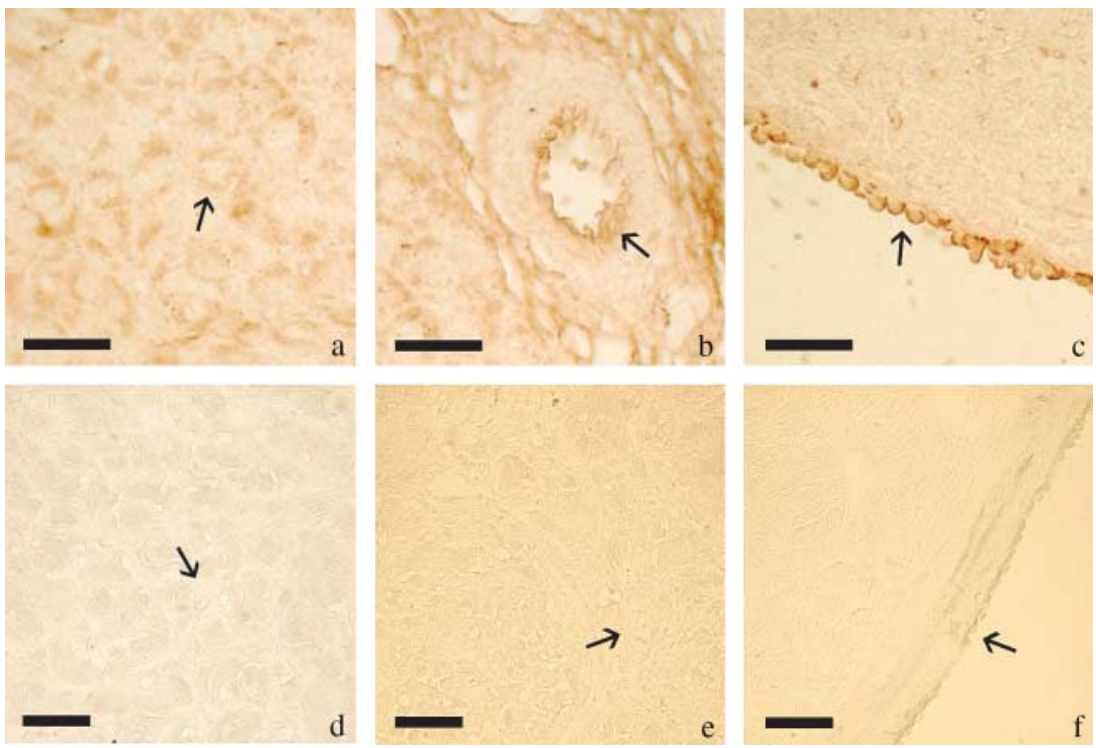

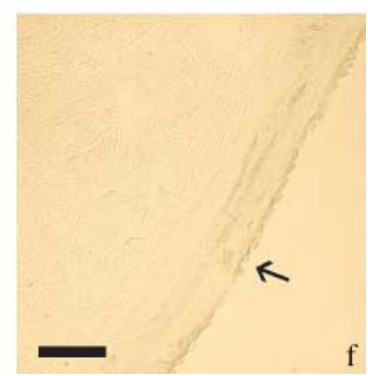

Figure 3 Cellular immunolocalization of COX-2 in rabbit ovaries collected at day 4 of pseudopregnancy before $(\mathrm{a}-\mathrm{c})$ PGF $2 \alpha$ analogue injection. In photos a-c, the arrows indicate the sites of positive immunoreaction: CL parenchima (a), vascular components of stromal arterioles (b), ovarian epithelium (c). Control sections in the absence of primary antibody $(d-f)$. Scale bar $=20 \mu \mathrm{m}$. values (Fig. 6, panel A). After PGF2 $\alpha$ treatment, COX-2 mRNA were more expressed $(P<0.01)$ at 3 and $6 \mathrm{~h}$ in day-9 than in day-4 CL (Fig. 6, panel A).

\section{COX-1 and COX-2 enzyme activity}

In un-stimulated does, basal luteal enzyme activity for COX-1 was similar at both stages of pseudopregnancy (Fig. 7, left panel), whereas that of COX-2 was higher $(P<0.01)$ at day 9 than at day 4 (Fig. 7 , right panel). In the early luteal stage, basal COX- 1 enzyme activity $(7464 \pm 1573$ d.p.m./mg protein) was higher $(P<0.01)$ than that of COX-2 $(3129 \pm 1006$ d.p.m./mg protein), while there was no difference in $\mathrm{CL}$ collected at day 9. Following PGF $2 \alpha$ challenge, the activity of COX-1 did not change neither at day 4 nor at day 9 , whereas that of COX-2 increased $(P<0.01)$ from 1.5 to $24 \mathrm{~h}$ in day- $4 \mathrm{CL}$ and from 1.5 to $12 \mathrm{~h}$ in day- $9 \mathrm{CL}$, when it decreased to basal level (Fig. 7, left panel). The enzymatic activity rate of COX-2 after PGF2 $\alpha$ was much higher $(P<0.01)$ in day-9 than in day-4 CL (Fig. 7, right panel).

\section{PGE2-9-K enzyme activity}

Basal luteal PGE2-9-K activity was lower $(P<0.01)$ at day 4 than at day 9 of pseudopregnancy (Fig. 8). PGF2 $\alpha$ injection increased $(P<0.01)$ PGE2-9-K activity from 1.5 to $12 \mathrm{~h}$ in day- $9 \mathrm{CL}$, while it was ineffective in early $\mathrm{CL}$ (Fig. 8).

\section{PGE2 and PGF2 $\alpha$ in vitro synthesis}

At day 4 of pseudopregnancy, intraluteal basal synthesis of PGE2 was higher $(P<0.01)$, while that of
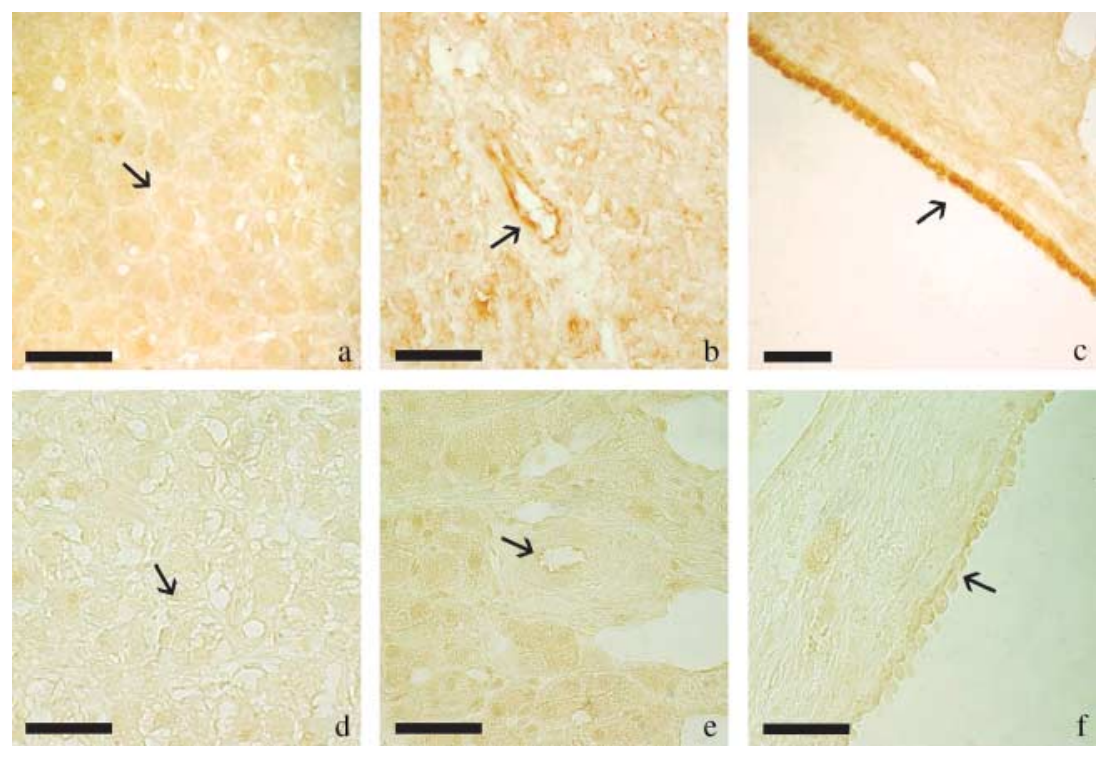

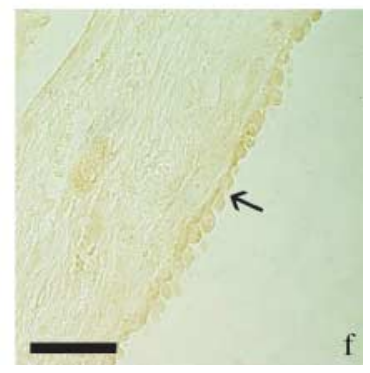

Figure 4 Cellular immunolocalization of COX-2 in rabbit ovaries collected at day 9 of pseudopregnancy before $(\mathrm{a}-\mathrm{c})$ PGF2 $\alpha$ analogue injection. In photos a-c, the arrows indicate the sites of positive immunoreaction: CL parenchima (a), vascular components of stromal arterioles (b), ovarian epithelium (c). Control sections in the absence of primary antibody $(d-f)$. Scale bar $=20 \mu \mathrm{m}$. 


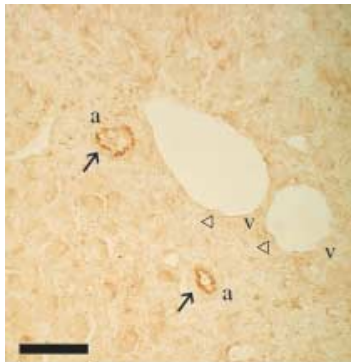

Figure 5 Positive COX-2 immunoreaction in rabbit stromal arterioles (a; arrows); in the same section the venules appeared negative ( $\mathrm{v}$; heads of arrows). The section was obtained from an ovary collected at day 4 of pseudopregnancy $3 \mathrm{~h}$ after PGF $2 \alpha$ injection. Scale bar $=20 \mu \mathrm{m}$

PGF2 $\alpha$ was lower $(P<0.01)$ compared with those at day 9 (Fig. 9) The PGE2 to PGF2 $\alpha$ basal synthesis ratio was higher $(P<0.01)$ at day $4(11.49 \pm 3.45)$ than at day $9(3.10 \pm 0.66)$.

In the early luteal stage, exogenous PGF $2 \alpha$ administration did not affect the enzyme-dependent PGE2 luteal synthesis in the following $24 \mathrm{~h}$, which markedly decreased $(P<0.01)$ at day 9 of pseudopregnancy (Fig. 9, left panel). On the contrary, following PGF2 $\alpha$ challenge, intraluteal PGF $2 \alpha$ synthesis increased $(P<0.01)$ within $1.5 \mathrm{~h}$ in both day-4 and day-9 $\mathrm{CL}$, but was much higher $(P<0.01)$ in day-9 than in day-4 CL (Fig. 9, right panel). PGE2 synthesis was negatively correlated with that of PGF $2 \alpha(\nu=18$, $r=-0.8093, P<0.01)$ and with PGE2-9-K activity $(\nu=$ $18, \quad r=-0.7135, P<0.01)$; conversely, PGF2 $\alpha$ was positively correlated with PGE2-9-K activity $(\nu=18, r=$ $0.8618, P<0.01)$.

\section{Discussion}

In this study, we present evidence of an auto-amplification mechanism within the rabbit CL for PGF2 $\alpha$ synthesis that implies activation of COX-2 and PGE2-9$\mathrm{K}$ enzymes and leads to luteal regression.

Our investigation revealed a widespread distribution of COX-2 immunostaining that was localized in several cell types within the rabbit ovary at both day 4 and 9 of pseudopregnancy either before or after exogenous PGF $2 \alpha$ injection. Similar distribution of COX-2 has been recently described in the human ovary (StavreusEvers et al. 2005). In bovine CL, across the oestrous cycle, independently of luteal stages, COX-2 protein is localized in large luteal cells, but not in other cell types (Arosh et al. 2004). In non-pregnant bitches, immunohistochemistry localized COX-2 expression in the cytoplasm of luteal cells during early dioestrus, but not during late ones (Kowalewski et al. 2006). On the contrary, in pseudopregnant rats COX-2 immunolabelling was seen in luteal steroid-producing and interstitial cells, but predominantly in non-luteal cells (Arend et al. 2004). In our study, positive COX-2 immunoreactivity was also evident in the ovarian surface epithelial cells, which are the site of an inflammatory-like response during ovulation (Rae et al. 2004).

Following PGF2 $\alpha$ challenge, luteal COX-2 mRNA expression was markedly up-regulated within $1.5 \mathrm{~h}$ at both day 4 and 9 of pseudopregnancy. However, thereafter the dynamic expression pattern of COX-2 transcript was different between early- and mid-luteal stages. In fact, in early $\mathrm{CL}$ the COX-2 mRNA levels remained at the same relatively high values, while in mature $\mathrm{CL}$ they peaked $3-6 \mathrm{~h}$ after PGF2 $\alpha$ injection to

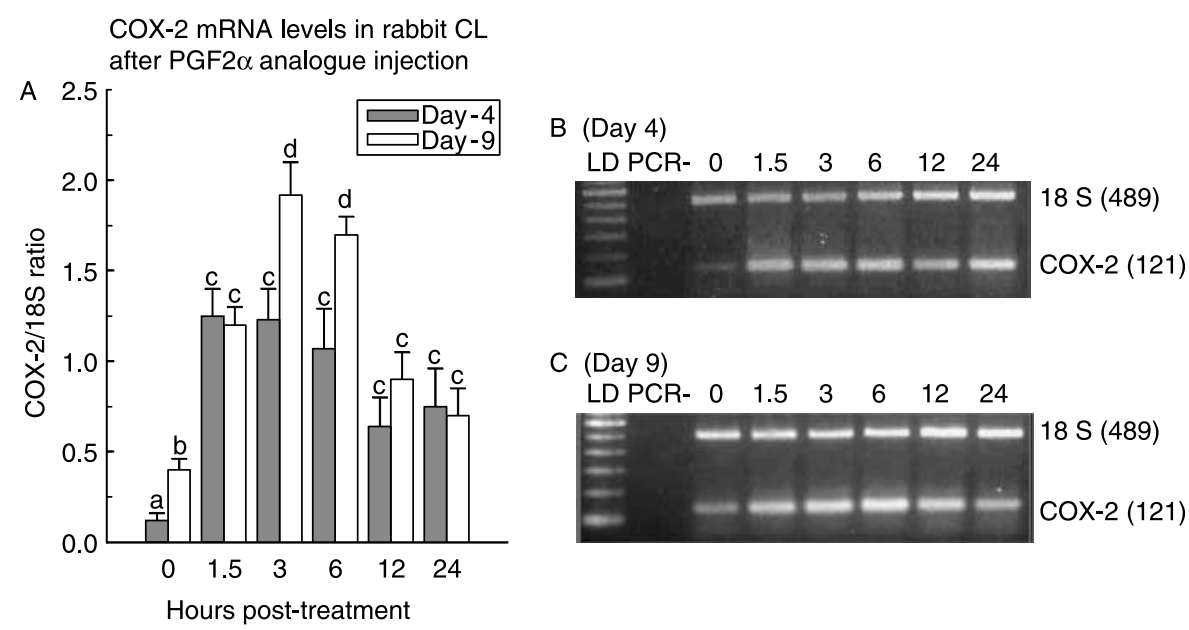

Figure 6 Gene expression patterns of COX-2 mRNAs in CL of rabbits collected at 0, 1.5, 3, 6, 12 and 24 h following PGF2 $\alpha$ analogue injection at days 4 or 9 of pseudopregnancy. Panel A summarizes the data (means \pm s.E.M.) derived from densitometric analyses of COX-2 in CL reported in arbitrary units relative to $18 \mathrm{~S}$ expression. For each day of pseudopregnancy, and for each time point, the values combine the results from three different rabbits. Different letters above bars indicate a significantly different value $(P<0.01)$. Panels B (day 4$)$ and C (day 9 ) show representative photographs of typical $2 \%$ agarose, ethidium bromide stained gels, showing the presence of the expected base pair products yielded after RT-PCR using primers for target COX-2 (121 bp) and $18 \mathrm{~S}$ (489 bp). Lane LD is the kilobase DNA marker, lane PCR represents a negative control of non-reverse-transcribed RNA submitted to PCR amplification, while the other lanes identify the corresponding hours after PGF2 $\alpha$ injection. 

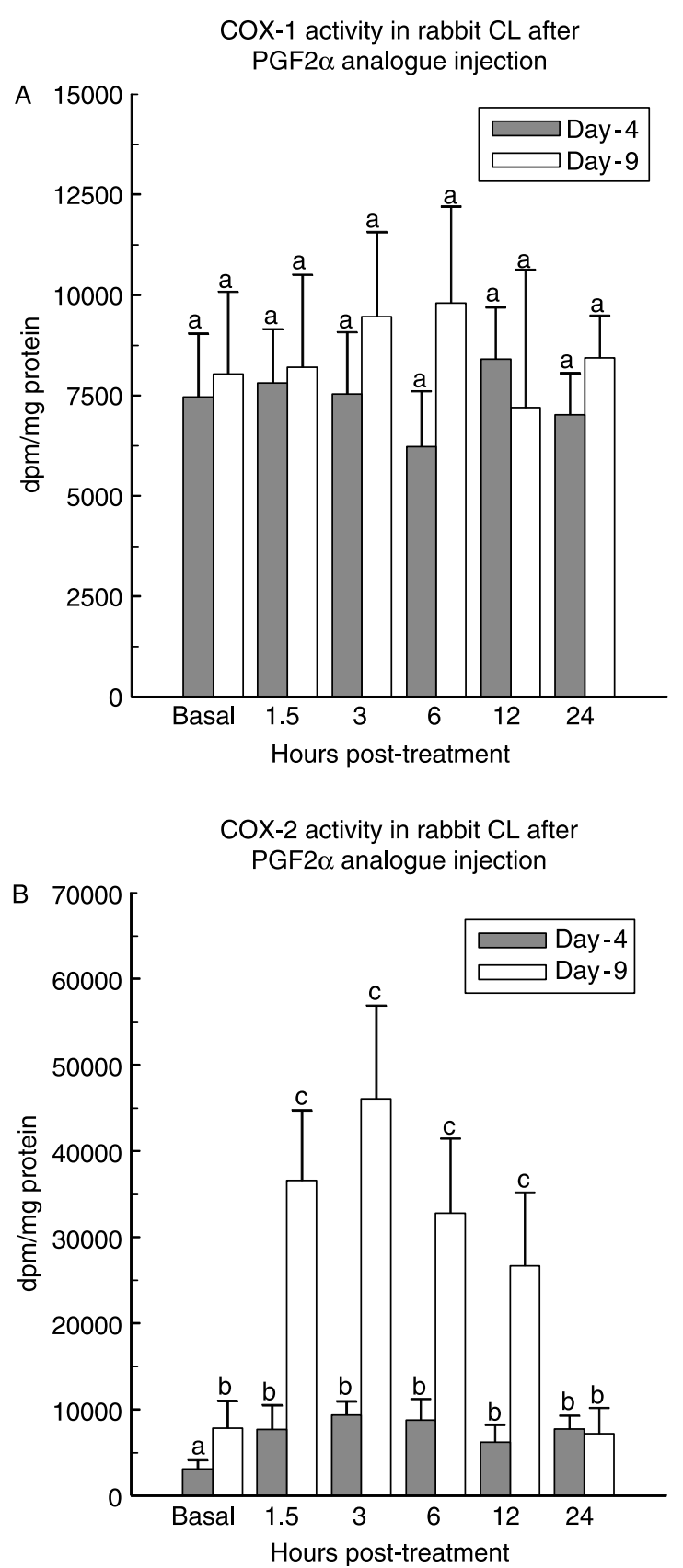

Figure 7 COX-1 (panel A) and COX-2 (panel B) activities in lysates of CL collected before and 1.5, 3, 6, 12 and $24 \mathrm{~h}$ after PGF2 $\alpha$ analogue administration at days 4 and 9 of pseudopregnancy. For each day of pseudopregnancy and for each time point, results are means \pm s.D. of combined values derived from three rabbits. Different letters above the bars indicate significantly different values $(P<0.01)$.

gradually decline within the following hours to low levels, but still higher with respect to pre-treatment ones. The results of the present study are in agreement with those of Narayansingh et al. (2002), who reported that in immature superovulated rats the administration of PGF2 $\alpha$ increased the luteal expression for COX-2

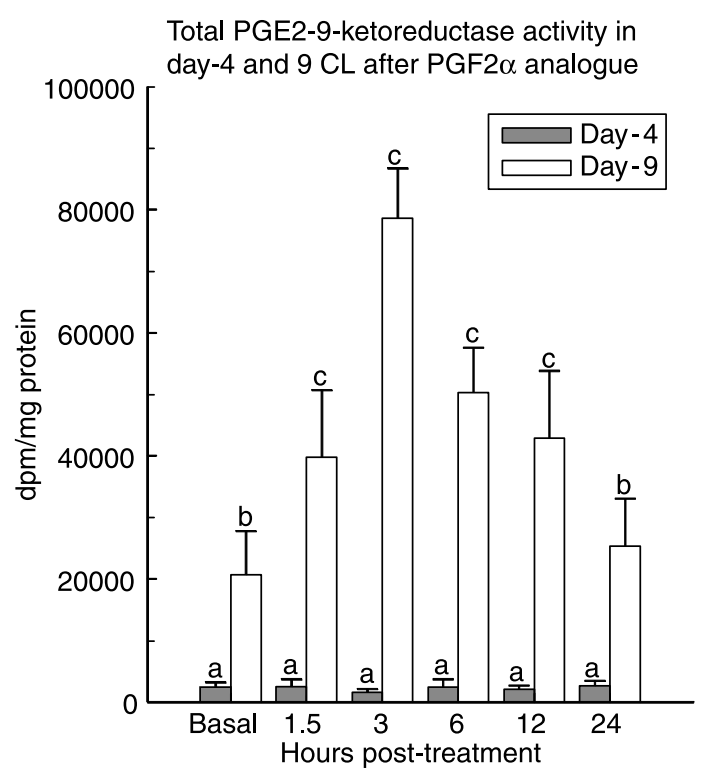

Figure 8 PGE2-9-K activities in lysates of CL collected before and 1.5, $3,6,12$ and $24 \mathrm{~h}$ after PGF2 $\alpha$ analogue administration at days 4 and 9 of pseudopregnancy. For each day of pseudopregnancy and for each time point, results are means \pm s.D. of combined values derived from three rabbits. Different letters above the bars indicate significantly different values $(P<0.01)$.

mRNA and protein, whereas COX-1 remained unchanged. Also in cows, COX-2 mRNA expression increased during the time course of PGF $2 \alpha$-induced luteolysis (Hayashi et al. 2003), while the COX-1 mRNA and related protein were constant during the different phases of the oestrous cycle (Arosh et al. 2004). In the dog, unlike other domestic animal species, luteal function is almost identical in pregnant and nonpregnant females and, in addition, PGF $2 \alpha$ seems to act as an endogenous luteolytic agent only during the immediate pre-partum decline in pregnant bitches (Hoffmann et al. 1999). In non-pregnant bitches, increased COX-2 expression was associated with luteal growth and not with $\mathrm{CL}$ regression, while COX-1 was constant during the dioestrus, suggesting that the COX-1 in generating prostanoids has a minor role in canine $\mathrm{CL}$ function (Kowalewski et al. 2006).

Our study revealed that the two luteal COX enzymes had different activity rates depending on the luteal stage examined. In fact, in both early- and mid-luteal phases of pseudopregnancy, COX-1 had the same activity, which was not affected by PGF2 $\alpha$ injection within the following $24 \mathrm{~h}$. On the contrary, basal COX-2 activity was higher in day-9 than in day-4 non-stimulated CL. In addition, PGF2 $\alpha$ increased its specific activity two- to threefold during the early luteal phase and by five- to tenfold in mid-phase.

Regarding the intraluteal PG production, early stage $\mathrm{CL}$, explanted from non-stimulated pseudopregnant rabbits, synthesized more PGE2 than older, mid-luteal 

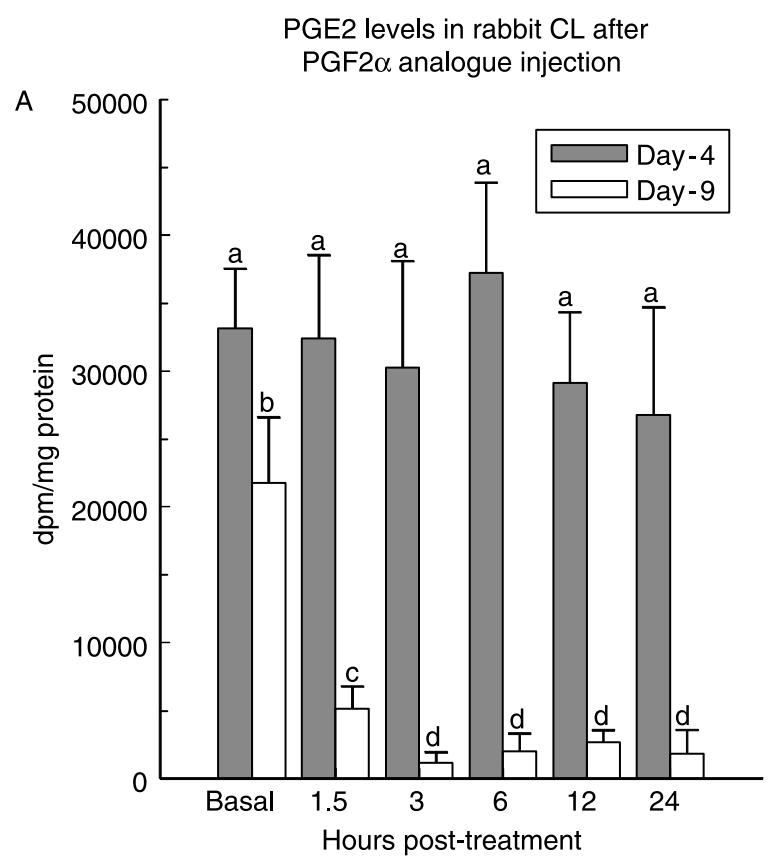

PGF2 $\alpha$ levels in rabbit CL after PGF2 $\alpha$ analogue injection

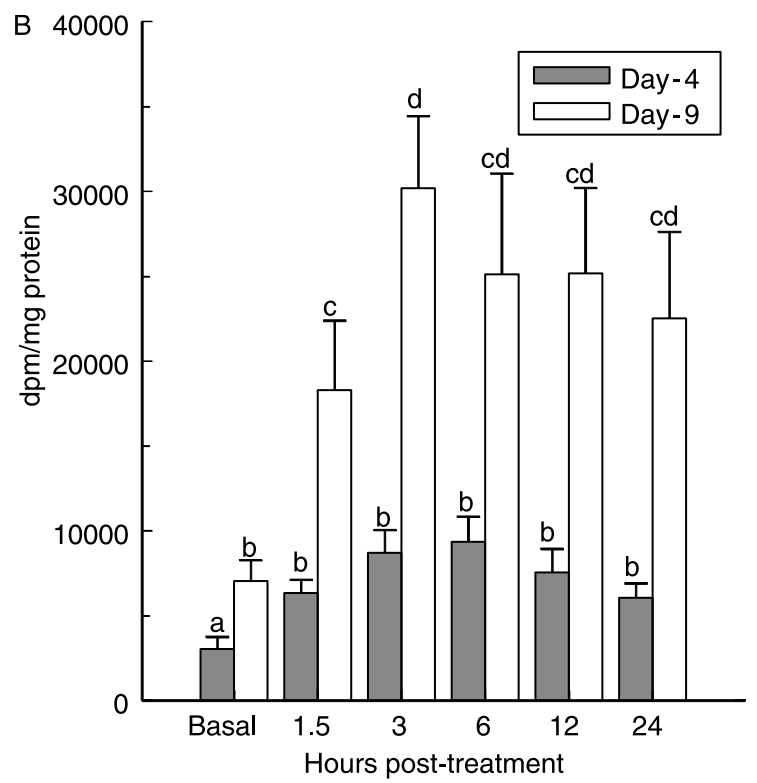

Figure 9 PGE2 (panel A) and PGF2 $\alpha$ (panel B) in vitro levels in lysates of $\mathrm{CL}$ collected before and 1.5, 3, 6, 12 and $24 \mathrm{~h}$ after PGF2 $\alpha$ analogue administration at days 4 and 9 of pseudopregnancy (left and right panels respectively). PGE2 and PGF2 $\alpha$ were determined by measuring the conversion of the $\left[{ }^{3} \mathrm{H}\right]$ arachidonic acid into $\left[{ }^{3} \mathrm{H}\right] \mathrm{PGE} 2$ and $\left.{ }^{3} \mathrm{H}\right] \mathrm{PGF} 2 \alpha$, respectively. For each day of pseudopregnancy and for each time point, results are means \pm s.D. of combined values derived from three rabbits. Different letters above the bars indicate significantly different values $(P<0.01)$.

stage $\mathrm{CL}$, while day-9 $\mathrm{CL}$ produced PGF2 $\alpha$ at a higher level compared with day-4 CL. Despite the different approach, our results are in good agreement with those reported by Arosh et al. (2004), who found that in growing $\mathrm{CL}$ of cows the expression of PGE2 synthase (PGES) protein was higher, whereas that of PGF synthase (PGFS) was lower. These authors reported that also the PGES/PGFS ratio was higher in growing CL of cows, in agreement with what we found in rabbits where the PGE/ PGF2 $\alpha$ ratio is higher in early luteal stage CL. In our animal model, after PGF2 $\alpha$ challenge, luteal PGE2 synthesis remained unaffected at day 4 , but markedly decreased at day 9. On the contrary, following PGF2 $\alpha$ injection, intraluteal PGF2 $\alpha$ synthesis was much higher at day 9 than at day 4 . These results are in agreement with our previous findings, where $\mathrm{CL}$ of rabbits were resistant to the luteolytic action of PGF $2 \alpha$ analogue, alfaprostol, injected at day 4 of pseudopregnancy, but acquired luteolytic capacity at day 9 (Boiti et al. 1998). A variety of species develops luteolytic capacity at different stages of the oestrous cycle, such as cows (Niswender et al. 2000), pigs (Guthrie \& Polge 1976), mares (Douglas \& Ginther 1975) and monkeys (Michael \& Webley 1993). In cows, the lack of luteolytic capacity in developing $\mathrm{CL}$ (days 1-5) is not due to low PGF2 $\alpha$ receptor number, because these receptors are already highly expressed at this stage (Tsai \& Wiltbank 1998), but rather to greater luteal PG dehydrogenase activity and lower PGF $2 \alpha$ synthetic capacity (Silva et al. 2000). In pigs, a single PGF2 $\alpha$ injection did not cause luteolysis prior to day 13 of the cycle (Diaz \& Wiltbank 2005). In this species, the lack of luteolytic capacity is not due to an absence of PGF2 $\alpha$ receptors on luteal cells or to a lack of physiological response to this PG, but to different responsiveness of DAX-1 (a member of the orphan nuclear receptor family), StAR protein and LH receptor to PGF2 $\alpha$ (Diaz \& Wiltbank 2005). In rabbits, the difference in luteolytic capacity during the luteal phases was explained with the different CL densities of PGF $2 \alpha$ receptors that increase four- to fivefold from early- to mid- and late-luteal phases (Boiti et al. 2001). We cannot exclude that the high PGE2/PGF2 $\alpha$ ratio, found in day- 4 $\mathrm{CL}$, is another explanation for the lack of luteolytic capacity in response to PGF2 $\alpha$.

The PGF $2 \alpha$ synthesis can occur through the conversion of PGH2, PGD2 or PGE2, by the enzymatic activity of PGH2-9,11-endoperoxide ketoreductase, PGD211-ketoreductase, or the PGE2-9-K respectively (Watanabe 2002). However, the latter enzyme has a key role because its activity rate modulates PGE2 and PGF2 $\alpha$ production levels. In our study, mid-luteal phase CL showed a higher level of PGE2-9-K basal activity than growing CL. PGF2 $\alpha$ injection increased the activity of this enzyme only in day-9 CL. The modulator role of PGE2-9-K enzyme in rabbit $C L$ is supported by the correlation of its enzymatic activity with PGE2 and PGF2 $\alpha$ synthesis, negative and positive respectively. Wintergalen et al. (1995) found that in rabbits, luteal PGE2-9-K exerts also 20 $\alpha$-hydroxysteroid dehydrogenase $(20 \alpha-H S D)$ catalytic activity, thus favouring the conversion of progesterone into the inactive metabolite 
$20 \alpha-\mathrm{OH}$-progesterone. In regards to this double enzymatic activity, Madore et al. (2003) reported that a $20 \alpha-H S D$ is present in the bovine endometrium and that this enzyme also has an aldose reductase activity and, thus, has the ability to terminate the oestrous cycle metabolizing progesterone and synthesizing PGF2 $\alpha$. Therefore, an essential role emerges for PGE2-9-K in the regulation of induced-luteolysis in rabbits, as it increases intraluteal PGF $2 \alpha$ while decreasing progesterone production in PGF $2 \alpha$-responsive CL.

The lack of effect of PGF2 $\alpha$ on luteal PGE2-9-K activity in day-4 CL could partly explain the modest PGF2 $\alpha$ induced intraluteal PGF $2 \alpha$ production increase at this luteal stage, a result that is in line with the lack of luteolytic capacity in early CL to this PG. Since PGE2-9$\mathrm{K}$ is not affected during the PGF2 $\alpha$-induced luteolysis in the early phase of pseudopregnancy, the intraluteal increase in PGF2 $\alpha$ production is likely due to $\mathrm{PGH} 2$ 9,11-endoperoxide ketoreductase and/or PGD211-ketoreductase. On the other hand, the absence of response of PGE2-9-K activity could explain, not only the low receptor number for PGF2 $\alpha$ (Boiti et al. 2001) but also PGF2 $\alpha$ ineffectiveness in inducing progesterone decrease during the early luteal phase.

Recently, it was suggested that extra-luteal production of PGF $2 \alpha$ initiates the inhibition of progesterone production accompanying functional luteolysis, while the intraluteal PGF2 $\alpha$ production contributes to structural luteolysis by the activation of an auto-amplification loop in CL of pig, sheep and cow (Diaz et al. 2000, Griffeth et al. 2002, Wiltbank \& Ottobre 2003, Arosh et al. 2004). A positive feedback loop triggered by PGF2 $\alpha$-FP receptor signalling was also found in endometrial adenocarcinoma cells; intracellular PGF2 $\alpha$, produced via the COX-2 action, is actively transported outside the cell and interacts with FP receptor in an autocrine/paracrine manner activating the intracellular signalling cascade to sustain endometrial tumorigenesis (Jabbour et al. 2005).

Our results show that also in rabbits, intraluteal PGF $2 \alpha$ intervenes in the luteolysis with an auto-amplification loop as summarized in Fig. 10. Depending on luteal

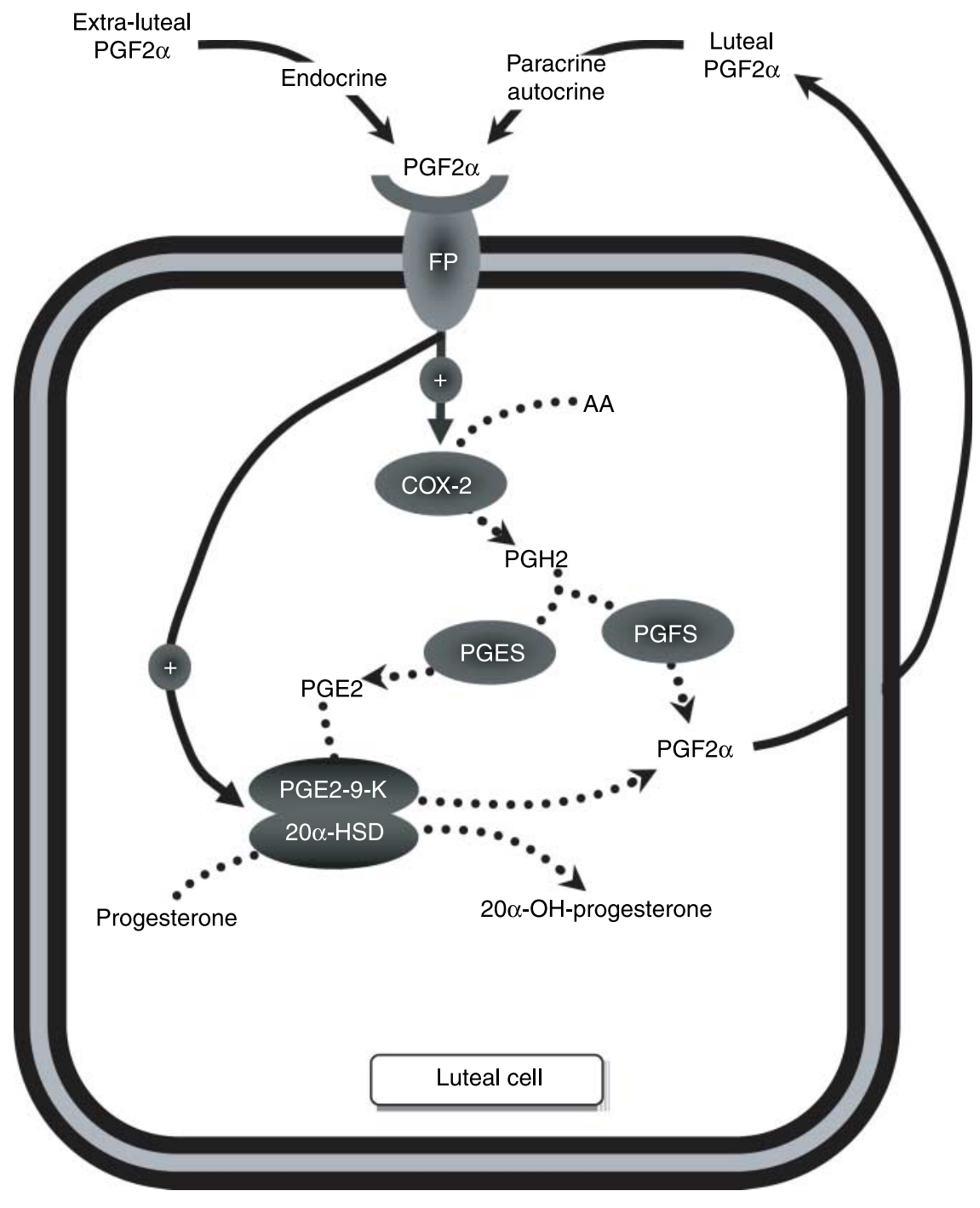

Figure 10 Schematic representation of the PF2 $\alpha$ auto-amplifying intracellular mechanisms in mid-luteal phase $\mathrm{CL}$ of pseudopregnant does. 20 $\alpha$-HSD, 20 $\alpha$ hydroxysteroid dehydrogenase; $\mathrm{AA}$, arachidonic acid; COX-2, cyclooxygenase-2; FP, PGF2 $\alpha$ receptor; PGE2, prostaglandin E2; PGE2-9-K, PGE2-9-ketoreductase; PGES, prostaglandin E2 synthase; PGF2 $\alpha$, prostaglandin F2 $\alpha$; PGFS, prostaglandin F2 $\alpha$ synthase; PGH2, prostaglandin H2. PGE2-9-K and 20a-HSD are joined as they represent a single enzyme with two different activities. PGFS represents the activity of two enzymes: PGH2-9,11-endoperoxide ketoreductase and PGD2-11-ketoreductase. 
stage, PGF2 $\alpha$ activates COX-2 and PGE2-9-K, the former enzyme metabolizes the arachidonic acid into $\mathrm{PGH} 2$, which is converted into PGF2 $\alpha$ and PGE2; this latter PG, in turn, is transformed into PGF $2 \alpha$ by the activated PGE2-9-K. This enzyme contemporaneously helps the PGF2 $\alpha$-induced progesterone decrease, metabolizing progesterone into $20 \alpha-\mathrm{OH}$-progesterone by its $20 \alpha-$ HSD activity.

Recently, Wiltbank \& Ottobre (2003) reported that luteal PGE2 production rose during luteolysis in ewes, and that this production was highly correlated to that of PGF2 $\alpha$. These authors asserted that both PG productions were mediated by the increased COX-2 activity during luteolysis, but also that this intraluteal PGE2 increase did not have a clear physiological function during luteolysis, since this PG has a luteal protective effect. Our results suggest a physiological role for late-luteal phase PGE2 production; in fact, this PG could be the main source of PGF2 $\alpha$ synthesis throughout the PGE2-9-K enzymatic activity.

In a recent study, it was proposed that luteal tissue PG biosynthesis is preferentially directed toward PGE2 rather than PGF2 $\alpha$ production (Arosh et al. 2004), since the conversion of $\mathrm{PGH} 2$ to PGE2 by PGE synthase is 150-fold higher than the conversion of $\mathrm{PGH} 2$ to PGF2 $\alpha$ by PGF synthase (Madore et al. 2003, Thoren et al. 2003). These studies together with our present results suggest an intriguing idea: both early- and midluteal stage rabbit $C L$ utilize the same intracellular enzymatic pathways (PLA2/AA $\rightarrow \mathrm{COX} 2 / \mathrm{PGH} 2 \rightarrow \mathrm{PGE}$ synthase/PGE2) to produce an initial PGE2 bulk, while the final $\mathrm{CL}$ production of PGE2 (early luteal stage) or PGF2 $\alpha$ (mid-luteal stage) depends on PGE2-9-K inactivation or activation respectively.

Even if the present data throw new light on the knowledge of some physiological mechanisms regulating intraluteal PG production, further studies are needed to better understand the fine tuning that controls rabbit $\mathrm{CL}$ life span.

\section{Acknowledgements}

This work was supported by a grant from Ministero dell'Istruzione, dell'Università e della Ricerca (Contract $\mathrm{n}$. 2005078028). The authors gratefully acknowledge the revision of the English text by Dr James Burge. The authors wish to thank Mrs G Mancini for her excellent technical assistance in the immunohistochemical studies. The authors declare that there is no conflict of interest that would prejudice the impartiality of this scientific work.

\section{References}

Arend A, Masso R, Masso M \& Selstam G 2004 Electron microscope immunocytochemical localization of cyclooxygenase- 1 and -2 in pseudopregnant rat corpus luteum during luteolysis. Prostaglandins and other Lipid Mediators 74 1-10.
Arosh JA, Banu SK, Chapdelaine P, Madore E, Sirois J \& Fortier MA 2004 Prostaglandin biosynthesis, transport and signaling in corpus luteum: a basis for autoregulation of luteal function. Endocrinology 145 2551-2560.

Boiti C, Canali C, Zerani M \& Gobbetti A 1998 Changes in refractoriness of rabbit Corpora lutea to a prostaglandin F2 $\alpha$ analogue, alfaprostol, during pseudopregnancy. Prostaglandins $\mathbf{5 6}$ $255-264$

Boiti C, Zerani M, Zampini D \& Gobbetti A 2000 Nitric oxide synthase activity and progesterone release by isolated corpora lutea of rabbits in early- and mid-luteal phase of pseudopregnancy are differently modulated by prostaglandin E-2 and prostaglandin F-2 $\alpha$ via adenylate cyclase and phospholipase C. Journal of Endocrinology 164 179-186.

Boiti C, Zampini D, Zerani M, Guelfi G \& Gobbetti A 2001 Prostaglandin receptors and role of $\mathrm{G}$ protein-activated pathways on corpora lutea of pseudopregnant rabbit in vitro. Journal of Endocrinology 168 141-151.

Boiti C, Guelfi G, Zampini D, Brecchia G, Gobbetti A \& Zerani M 2003 Regulation of nitric-oxide synthase isoforms and role of nitric oxide during prostaglandin F2alpha-induced luteolysis in rabbits. Reproduction 125 807-816.

Boiti C, Guelfi G, Brecchia G, Dall'Aglio C, Ceccarelli P, Maranesi M, Mariottini C, Zampini D, Gobbetti A \& Zerani M 2005 Role of endothelin-1 system in the luteolytic process of pseudopregnant rabbits. Endocrinology 146 1293-1300.

Browning JY, Keyes PF \& Wolf RC 1980 Comparison of serum progesterone, $20 \alpha$-dihydroprogesterone, and estradiol-17 $\beta$ in pregnant and pseudopregnant rabbits: evidence for postimplantation recognition of pregnancy. Biology of Reproduction 23 1014-1019.

Davis JS \& Rueda BR 2002 The corpus luteum: an ovarian structure with maternal instincts and suicidal tendencies. Frontiers in Bioscience 7 1949-1978.

Diaz FJ \& Wiltbank MC 2005 Acquisition of luteolytic capacity involves differential regulation by prostaglandin F2 $\alpha$ of genes involved in progesterone biosynthesis in the porcine corpus luteum. Domestic Animal Endocrinology 28 172-189.

Diaz FJ, Crenshaw TD \& Wiltbank MC 2000 Prostaglandin F2 $\alpha$ induces distinct physiological responses in porcine corpora lutea after acquisition of luteolytic capacity. Biology of Reproduction 63 1504-1512.

Diaz FJ, Anderson LE, WU YL, Rabot A, Tsai SJ \& Wiltbank MC 2002 Regulation of progesterone and prostaglandin F2 $\alpha$ production in the CL. Molecular and Cellular Endocrinology 191 65-80.

Douglas RH \& Ginther OJ 1975 Effects of prostaglandin F2alpha on the oestrous cycle and pregnancy in mares. Journal of Reproduction and Fertilility 23 257-261.

Duncan DB 1955 Multiple range and multiple F test. Biometrics 11 $1-42$.

Gobbetti A \& Zerani M 1995a Prostaglandin E2-9-ketoreductase and prostaglandin F2 alpha activate brain aromatase to induce courtship in the male crested newt, Triturus carnifex. Hormones and Behavior 29 267-277.

Gobbetti A \& Zerani M 1995b Amphibian oocyte: a model of a possible regulatory mechanism for prostaglandin E2 and prostaglandin F2alpha synthesis. Journal of Endocrinology 145 235-241.

Gobbetti A, Boiti C, Canali C \& Zerani M 1999 Nitric oxide synthase acutely regulates progesterone production by in vitro cultured rabbit corpora lutea. Journal of Endocrinology 160 275-283.

Griffeth RJ, Nett TM, Burns PD, Escudero JM, Inskeep EK \& Niswender GD 2002 Is luteal production of PGF2 $\alpha$ required for luteolysis? Biology of Reproduction 66465.

Guthrie H \& Polge C 1976 Luteal function and oestrus in gilts treated with a synthetic analogue of prostaglandin $\mathrm{F} 2 \alpha$ at various times during the oestrous cycle. Journal of Reproduction and Fertilility $\mathbf{4 8}$ 423-425. 
Hayashi K, Acosta TJ, Berisha B, Kowayashi S, Ohtani M, Schams D \& Miyamoto A 2003 Changes in prostaglandin secretion by the regressing bovine corpus luteum. Prostaglandins and other Lipid Mediators 70 339-349.

Helliwell RJA, Adams LF \& Mitchell MD 2004 Prostaglandin synthases: recent developments and a novel hypothesis. Prostaglandins Leukotrienes and Essential Fatty Acids 70 101-113.

Hoffmann B, Riesenbeck A, Schams D \& Steinetz BG 1999 Aspects of hormonal control and induced parturition in the dog. Reproduction of Domestic Animals 34 219-226.

Jabbour HN, Sales KJ, Boddy SC, Anderson RA \& Williams ARW 2005 A positive feedback loop that regulates cyclooxygenase-2 expression and prostaglandin F2 $\alpha$ synthesis via F-series-prostanoid receptor and extracellular signal-regulated kinase $1 / 2$ signalling pathway. Endocrinology 146 4657-4664.

Keyes PL \& Bullock DW 1974 Effects of prostaglandin F2alpha on ectopic and ovarian corpora lutea of the rabbit. Biology of Reproduction 10 519-525.

Kowalewski MP, Schuler G, Taubert A, Engel E \& Hoffmann B 2006 Expression of cyclooxygenase 1 and 2 in the canine corpus luteum during diestrus. Theriogenology 66 1423-1430.

Lytton FDC \& Poyser NL 1982 Concentrations of PGF-2 $\alpha$ and PGE-2 in the uterine venous blood of rabbits during pseudopregnancy and pregnancy. Journal of Reproduction and Fertility 64 421-429.

Madore E, Harvey N, Parent J, Chapdelaine P, Arosh JA \& Fortier MA 2003 An aldose reductase with $20 \alpha$-hydroxysteroid dehydrogenase activity is most likely the enzyme responsible for the production of prostaglandin F2 $\alpha$ in the bovine endometrium. Journal of Biological Chemistry 278 11205-11212.

McCracken JA, Custer EE \& Lamsa JC 1999 Luteolysis: a neuroendocrine-mediated event. Physiological Reviews 79 263-323.

Michael AE \& Webley GE 1993 Roles of cyclic AMP and inositol phosphates in the luteolytic action of cloprostenol, a prostaglandin F2 alpha analogue, in marmoset monkeys (Callithrix jacchus). Journal of Reproduction and Fertilility 97 425-431.

Narayansingh RM, Senchyna M \& Carlson JC 2002 Treatment with prostaglandin F2alpha increases expression of prostaglandin synthase-2 in the rat corpus luteum. Prostaglandins and other Lipid Mediators 70 145-160.

Niswender GD, Juengel JL, Silva PJ, Rollyson MK \& McIntush EW 2000 Mechanisms controlling the function and life span of the corpus luteum. Physiological Reviews 80 1-29.

O'Grady JP, Kohorn EI, Glass RH, Caldwell BV, Brock WA \& Speroff L 1972 Inhibition of progesterone synthesis in vitro by prostaglandin F2. Journal of Reproduction and Fertility 30 153-156.

Olofsson JI \& Leung PCK 1996 Prostaglandins and their receptors: implications for ovarian physiology. Biological Signals 5 90-100.

Parthasarathy S, Wieland E \& Steinberg D 1989 A role for endothelial cell lipoxygenase in the oxidative modification of low density lipoprotein. PNAS 86 1046-1050.

Rae MT, Niven D, Critchley HO, Harlow CR \& Hillier SG 2004 Antiinflammatory steroid action in human ovarian surface epithelial cells. Journal of Clinical Endocrinology and Metabolism 89 4528-4544.
Sakurai T, Tamura K, Okamoto S, Hara T \& Kogo H 2003 Possible role of cyclooxygenase 2 in the acquisition of ovarian luteal function in rodents. Biology of Reproduction 69 835-842.

Sakurai T, Tamura K \& Kogo H 2005 Stimulatory effects of eicosanoids on ovarian angiogenesis in early luteal phase in cyclooxygenase-2 inhibitor-treated rats. European Journal of Pharmacology $\mathbf{5 1 6}$ 158-164.

Schlegel W, Daniels D \& Kruger S 1987 Partial purification of prostaglandin E2-9-ketoreductase and prostaglandin-15-hydroxydehydrogenase from ovarian tissues of rabbits. Clinical Physiology and Biochemistry 5 336-342.

Silva PJ, Juengel JL, Rollyson MK \& Niswender GD 2000 Prostaglandin metabolism in the ovine corpus luteum: catabolism of prostaglandin F2 $\alpha$. Biology of Reproduction 63 1229-1236.

Simmons DL, Botting RM \& Hla T 2004 Cyclooxygenase isozymes: the biology of prostaglandin synthesis and inhibition. Pharmacological Reviews $\mathbf{5 6}$ 387-437.

Smith WL, Garavito RM \& De Witt DL 1996 Prostaglandin endoperoxide $\mathrm{H}$ synthase (cyclooxygenase)-1 and -2. Journal of Biological Chemistry 271 33157-33160.

Sokal RR \& Rohlf FJ 1981 Biometry, New York: WH Freeman and Co.

Stavreus-Evers A, Koraen L, Scott JE, Zhang P \& Westlund P 2005 Distribution of cyclooxygenase-1, cyclooxygenase-2, and cytosolic phospholipase A2 in the luteal phase human endometrium and ovary. Fertility and Sterility 83 156-162.

Stradaioli G, Verini-Supplizi A, Monaci M, Canali C \& Boiti C 1997 Effects of different doses of PMSG on ovarian response and in vitro embryo development in rabbit. Word Rabbit Science 3 143-148.

Thoren S, Weinarder R, Saha S, Jegerschold C, Petterson PL \& Jacobsson PJ 2003 Human microsomal prostaglandin E synthase-1. Journal of Biological Chemistry 278 22199-22209.

Tsai S-J \& Wiltbank MC 1998 Prostaglandin F2 $\alpha$ regulates distinct physiological changes in early and mid-cycle bovine corpora lutea. Biology of Reproduction 58 346-352.

Watanabe K 2002 Prostaglandin F synthase. Prostaglandins and other Lipid Mediators 68-69 401-407.

Wiltbank MC \& Ottobre JS 2003 Regulation of intraluteal production of prostaglandins. Reproductive Biology and Endocrinology 191.

Wintergalen N, Thole Hh, Galla Hj \& Schlegel W 1995 ProstaglandinE2-9-reductase from corpus-luteum of pseudopregnant rabbit is a member of the aldo-keto reductase superfamily featuring 20-alphahydroxysteroid dehydrogenase-activity. European Journal of Biochemistry 234 264-270.

Xu XH, Burgess JR \& Teegarden D 1997 Increased prostaglandin H synthase-1 expression and activity level in stably Harvey-rat transfected C3H10T1/2 cells. Cancer Letters 119 87-92.

Zerani M, Boiti C, Zampini D, Brecchia G, Dall'Aglio C, Ceccarelli P \& Gobbetti A $2005 \mathrm{Ob}$ receptor in rabbit ovary and leptin in vitro regulation of corpora lutea. Journal of Endocrinology 183 279-288.

Received 15 July 2006

First decision 29 August 2006

Revised manuscript received 11 January 2007

Accepted 23 January 2007 